\title{
Article \\ The Effect of Antagonist Abiotic Stress on Bioactive Compounds from Basil (Ocimum basilicum)
}

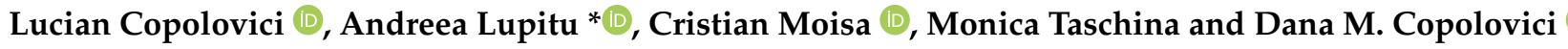 \\ Faculty of Food Engineering, Tourism and Environmental Protection, Institute for Research, Development and \\ Innovation in Technical and Natural Sciences, Aurel Vlaicu University, Romania, Elena Dragoi St. No. 2, \\ 310330 Arad, Romania; lucian.copolovici@uav.ro (L.C.); moisa.cristian@yahoo.com (C.M.); \\ mtaschina@yahoo.com (M.T.); dana.copolovici@uav.ro (D.M.C.) \\ * Correspondence: pag.andreea@yahoo.com
}

Citation: Copolovici, L.; Lupitu, A.; Moisa, C.; Taschina, M.; Copolovici, D.M. The Effect of Antagonist Abiotic Stress on Bioactive Compounds from Basil (Ocimum basilicum). Appl. Sci. 2021, 11, 9282. https://doi.org/ 10.3390/app11199282

Academic Editors: Ivelina Desseva and Dasha Mihaylova

Received: 3 September 2021

Accepted: 1 October 2021

Published: 6 October 2021

Publisher's Note: MDPI stays neutral with regard to jurisdictional claims in published maps and institutional affiliations.

Copyright: (c) 2021 by the authors. Licensee MDPI, Basel, Switzerland. This article is an open access article distributed under the terms and conditions of the Creative Commons Attribution (CC BY) license (https:/ / creativecommons.org/licenses/by/ $4.0 /)$.
Featured Application: The volatile organic compounds emission from plants could be used as an indicator of stress.

Abstract: Drought and flooding are some of the most common stressful conditions for plants. Due to the recent climate changes, they can occur one after another. This study is focused on the effect of antagonistic abiotic stress such as drought and flooding on the different metabolites from Ocimum basilicum leaves. Six-week-old plants of Ocimum basilicum were exposed to drought or flooding stress for 15 days, followed by antagonist stress for 14 days. The assimilation rates decrease drastically for plants under consecutive stresses from 18.9 to $0.25 \mu \mathrm{mol} \mathrm{m}^{-2} \mathrm{~s}^{-1}$ starting at day 3 of treatment. The stomatal conductance to water vapor $g_{s}$ was also reduced from 86 to $29 \mathrm{mmol} \mathrm{m}^{-2} \mathrm{~s}^{-1}$. The emission of green leaf volatiles compounds increases from 0.14 to $2.48 \mathrm{nmol} \mathrm{m}^{-2} \mathrm{~s}^{-1}$, and the emission of monoterpenes increased from 2.00 to $7.37 \mathrm{nmol} \mathrm{m}^{-2} \mathrm{~s}^{-1}$. The photosynthetic pigment concentration (chlorophyll $a$ and $b$, and $\beta$-carotene), the flavonoid content, and total phenolic content decrease for all stressed plants. The results obtained in this study could indicate that the water status (drought and/or flooding) directly impacts basil plants' physiological parameters and secondary metabolites.

Keywords: abiotic stress; basil; bioactive compounds; green leaf volatiles; photosynthesis; volatile organic compounds

\section{Introduction}

Basil (Ocimum basilicum), also known as sweet basil, is a medicinal plant from the Lamiaceae family. Basil plants are being used in various industries, including pharmaceutical, cosmetics, food, and in religious ceremonies [1,2]. Due to its remarkable properties, i.e., antidiabetic, wound healing, antioxidant, radiation protective, immunomodulatory, antifertility, anti-inflammatory, antimicrobial, antistress, and anticancer activities, basil could be exploited in traditional medicine [1,3-5].

The chemical composition of basil plants depends on the variety, geographic origin, time of harvesting, and growth conditions [6,7]. Basil's essential oil composition depends on the cultivar [8]. For example, Ocimum basilicum var. purpureum essential oil has mainly methyl chavicol (57.3\%), while the principal chemical component in Ocimum basilicum var. thyrsiflora is linalool (68\%) [7]. In a study that included 38 different genotypes of Ocimum basilicum L., it was shown that seven chemotypes-high-linalool, linalool-eugenol, methyl chavicol, methyl chavicol-linalool, methyl eugenol-linalool, methyl cinnamatelinalool, and bergamotene-could be detected [9]. In another study with 27 cultivars, only five chemotypes were proposed: eugenol-linalool, linalool, estragole-linalool, methyl cinnamate, and estragole [10].

The composition of volatile organic compounds (VOCs) emitted from plants can be quite different from the chemical composition of essential oils [6,11]. VOCs are emitted as 
a response to abiotic and biotic stress $[6,11,12]$. The VOCs that can be found in basil plant emissions are monoterpenes ( $\beta$-myrcene, $\beta$-pinene, cis and trans $\beta$-ocimene, camphene, limonene, camphor, cis- $\beta$-terpineol, $\beta$-linalool, terpinen-4-ol, $\alpha$-terpineol, bornyl acetate), sesquiterpenes ( $\beta$-elemene, $\alpha$-bergamotene), phenylpropanoids (eugenol, methyl eugenol, eugenol acetate, methyl chavicol), and fatty acid-derivative esters (octyl acetate, 1-octenyl acetate) $[6,13]$.

Several studies conducted on basil plants found that their major phenolic compounds are: rosmarinic, chicoric, caffeic, caftaric, 4-hydroxybenzoic, salvianic acid, quercetin, kaempferol, and anthocyanins [14-16].

In recent years, more and more studies support the fact that climate can change rapidly $[17,18]$ and can alter biological diversity and crop production. Environmental stress can be defined as changes in growth conditions within the plant's natural habitat [19].

In general, environmental stress can be divided into two types: biotic (bacteria, fungi, and insects) and abiotic. Abiotic stress, such as water availability (drought and flooding), temperature, heavy metals, salinity, and light intensity, can influence plant development and crop yield [19].

The tolerance to abiotic stress, respectively drought and flooding, can be observed in all plants, but the tolerance level differs from species to species [20]. Plants respond to drought and flooding by various molecular genetic expressions, biochemical metabolism, and physiological processes [21]. In case of water deficiency, the plants can produce osmotic adjustments, increase cell wall elasticity to preserve tissue turgidity [21], and increase side chains of the pectic polymers [22]. A decrease in cell wall thickness was noticed in Black spruce under drought stress [23]. Another response to limit the effect of drought stress is restricting the leaf transpiration surface [24]. The impact of drought stress can be modified by applying a reduced intensity of light [25].

The importance of abiotic stresses to agriculture can be easily observed, considering that abiotic factors significantly limit crop yield worldwide and reduce productivity [26]. Many lands are exposed to abiotic stresses (e.g., drought, flooding, changes in temperature, light intensity, salinity). This fact is expected to increase due to climate change and anthropogenic activities [19]. Drought and flooding are key factors affecting productivity across world ecosystems [27]. The phenylpropanoid pathway is usually activated under stressful conditions (drought, flooding, temperature changes), leading to modifications in the composition of plant extracts [19]. The response of basil plants to abiotic stress has been extensively studied [6,28-33]; however, the physiological and biochemical response to antagonist drought-flooding stress on basil plants has not been reviewed.

This study aims to evaluate the impacts of the antagonist abiotic stress of drought-flooding on basil plants. The photosynthetic parameters (net assimilation rate and stomatal conductance to water vapor), volatile organic compounds (VOC), chlorophylls content, flavonoids, and phenolic compounds are expected to change over the time of stress application (29 days).

\section{Materials and Methods}

\subsection{Plant Material}

Experiments were carried out in 2020 using six-week-old plants of Ocimum basilicum (lot 1GRS. 7A/349702, Hori Tops, Holland) sawn in 0.5 L plastic pots filled with commercial garden soil and grown in growth chambers under controlled conditions of light $(1000 \mu \mathrm{mol}$ $\left.\mathrm{m}^{-2} \mathrm{~s}^{-1}\right)$, temperature $\left(25^{\circ} \mathrm{C}\right)$, and humidity $(60-70 \%)$, and watered daily to field capacity.

As has been depicted in Figure 1, basil plants were subjected to drought stress for 15 days. Then, for 14 days, a part of those plants was watered normally (drought recovery plants), and the other part was subjected to flooding (drought flooding plants), also for 14 days. Other basil plants were subjected to flooding stress for 15 days. Then, for 14 days, a part of those plants was watered normally (flooding recovery plants), and the other part was subjected to drought (flooding drought plants), also for 14 days [34]. 


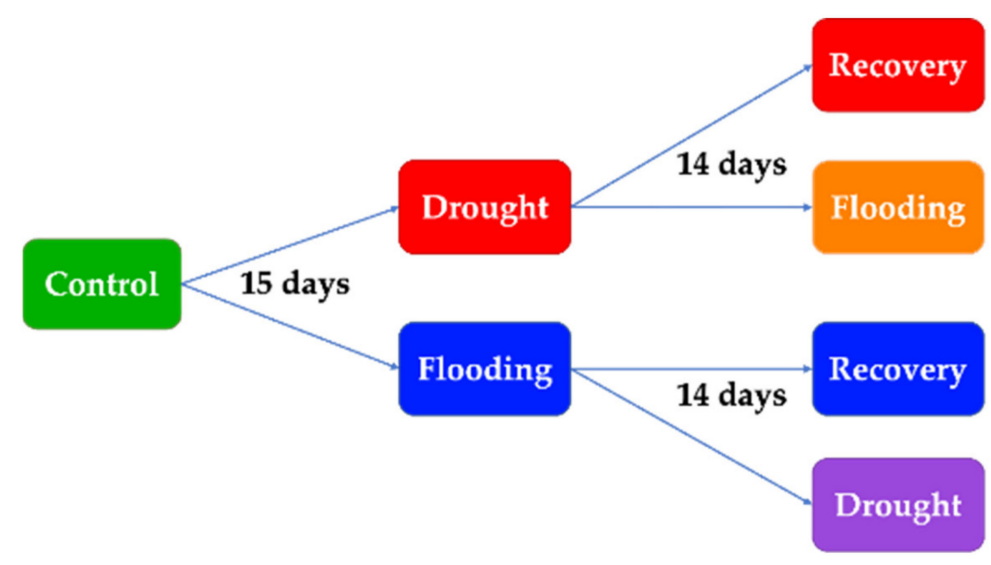

Figure 1. The design of the experimental plan.

\subsection{Photosynthetic Measurements}

Photosynthetic parameters were determined with a portable gas exchange system GFS3000 (Waltz, Effeltrich, Germany) [35], except for minor modifications in environmental conditions as stated below. This system has an environmental-controlled cuvette with an $8 \mathrm{~cm}^{2}$ window area and a full-window leaf chamber fluorimeter for sample illumination and fluorescence measurements. Each time, a leaf was measured at the following established conditions: light intensity of $1000 \mu \mathrm{mol} \mathrm{m}{ }^{-2} \mathrm{~s}^{-1}$, leaf temperature of $25^{\circ} \mathrm{C}$, chamber air humidity of $65 \%$, and $\mathrm{CO}_{2}$ concentration of $400 \mathrm{mmol} \mathrm{mol}^{-1}$. The leaf was stabilized under the standard conditions until stomata opened and steady-state $\mathrm{CO}_{2}$ and water vapor exchange rates were reached. Steady-state values of net assimilation (A) and stomatal conductance to water vapor $\left(g_{s}\right)$ were calculated as described before [36].

\subsection{Volatile Sampling and GC-MS Analyses}

Volatile organic compounds (VOC) were sampled via the outlet of the gas-exchange

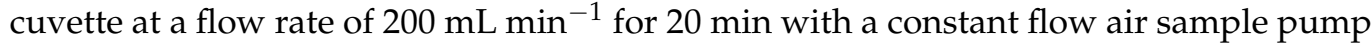
210-1003 MTX (SKC Inc., Houston, TX, USA), using the procedure described before [12]. The adsorbent cartridges were analyzed using a Shimadzu TD20 automated cartridge desorber integrated with a Shimadzu 2010 Plus GC-MS instrument (Shimadzu Corporation, Kyoto, Japan) according to the method of [37] and [36]. The background (blank) VOC concentrations were subtracted from the concentrations with leaf samples, and volatile emission rates were calculated as described before [38].

\subsection{Chromatographic Analysis of Photosynthetic Pigments}

Basil leaf samples of $4 \mathrm{~cm}^{2}$ were frozen in liquid nitrogen. The pigments were extracted in ice-cold acetone (70\%) as described before [39]. Each extraction was performed in three parallel samples.

Chlorophyll $a$, chlorophyll $b$, and $\beta$-carotene were evaluated using the UHPLC (NEXERA8030, Shimadzu, Japan) equipped with a diode array detector (DAD), using the procedure described before [12].

\subsection{Flavonoid Content Analysis}

The extracts obtained previously were used to determine the flavonoid content using a method with slight modifications [39]. Briefly, $0.250 \mathrm{~mL}$ sample were mixed with $1.250 \mathrm{~mL}$ sodium acetate $(100 \mathrm{~g} / \mathrm{L}), 0.750 \mathrm{~mL}$ of aluminum chloride $(25 \mathrm{~g} / \mathrm{L})$, and $0.250 \mathrm{~mL}$ of water. After $15 \mathrm{~min}$, the absorbance was measured at $434 \mathrm{~nm}$ against a blank sample prepared in the same conditions, using a double-beam UV-VIS spectrophotometer (Specord 200, Analytik Jena Inc., Jena, Germany). The calibration curve was prepared using rutin as a standard in the range of concentrations $0.02-0.4 \mathrm{mg}$ rutin equivalents $/ \mathrm{mL}$. The results were expressed in $\mathrm{mg}$ rutin equivalents $/ \mathrm{mL}$. All analyses were performed in triplicate, and the results were reported as mean. 


\subsection{Total Phenolic Content-Folin-Ciocalteu Method}

The extracts were obtained using fresh leaves 1:10 (w/v) in 60\% methanol by maceration for 7 days at $+4{ }^{\circ} \mathrm{C}$. All extracts were filtered using $0.45 \mu \mathrm{m}$ PTFE membrane. Total phenolic content was evaluated according to the Folin-Ciocalteu method with slight modifications $[40,41]$.

\subsection{Statistical Analysis and Data Handling}

One-way ANOVA followed by Dunnett's multiple comparisons test was performed using GraphPad Prism version 9.2.0 for Windows (GraphPad Software, San Diego, CA, USA). Analysis of variance (ANOVA one-way) for statistical data analysis was used. Data sharing different letters are significantly different $(p<0.05)$, while data sharing the same letters are not significantly different $(p>0.05)$.

\section{Results}

\subsection{Effects of Antagonist Stresses on Photosynthetic Characteristics}

The antagonistic effect of drought-flooding on the photosynthetic parameters of basil leaves was assessed by measuring the net assimilation rate $(A)$ and stomatal conductance to water vapor $\left(g_{s}\right)$ (Figure 2).

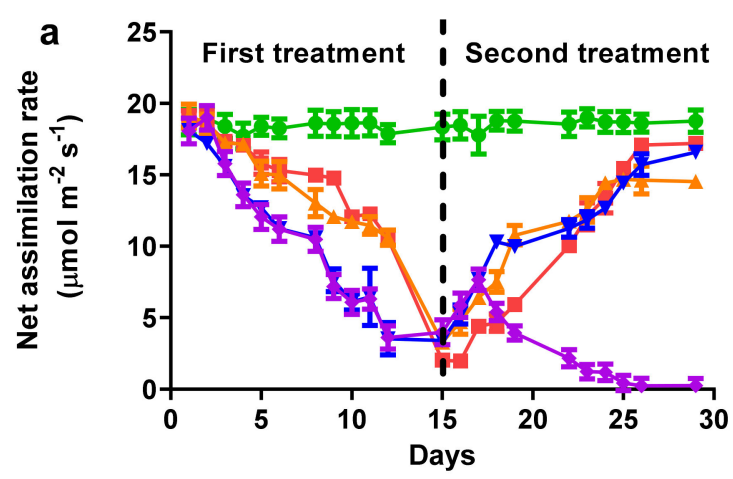

(a)

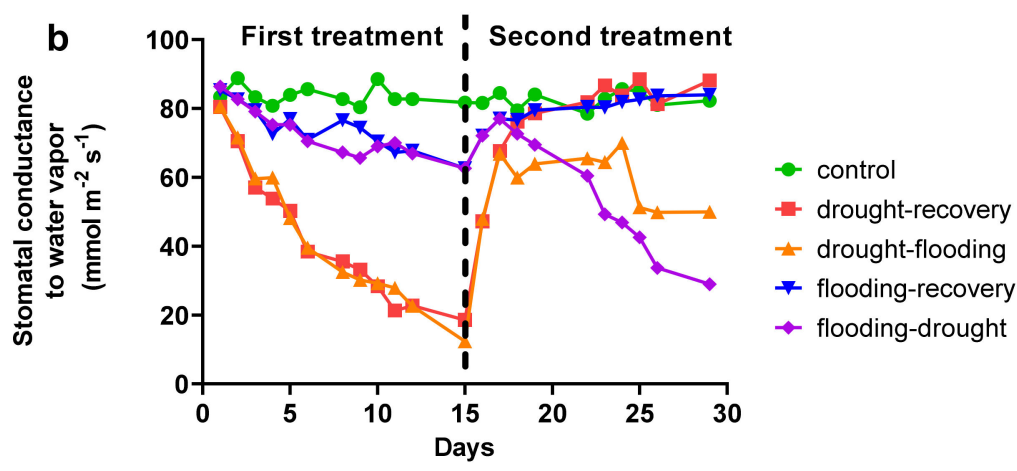

(b)

Figure 2. The net assimilation rate (a) and stomatal conductance to water vapor (b) from $O$. basilicum plants under different stress conditions. The values are averages of three independent measurements.

On day 1 , there were no differences among treatments in all measured parameters, indicating the uniformity of the selected plants for the experiment. A noticeable reduction of $A$ (from 18.9 to $17.3 \mu \mathrm{mol} \mathrm{m}{ }^{-2} \mathrm{~s}^{-1}$ ) and $g_{s}$ (from 86 to $70 \mathrm{mmol} \mathrm{m}^{-2} \mathrm{~s}^{-1}$ ) has been started at day three for plants subjected to drought stress. At basil plants subjected to flooding, a reduction of $A$ (from 18.9 to $15.6 \mu \mathrm{mol} \mathrm{m}{ }^{-2} \mathrm{~s}^{-1}$ ) and $g_{s}$ (from 86 to $79 \mathrm{mmol} \mathrm{m}^{-2} \mathrm{~s}^{-1}$ ) was observed on day 3 . There is a constant decrease in photosynthetic parameters over the entire period for both stresses, but $g_{s}$ is less affected by flooding than drought stress. On day 15, the last day of the first treatment (drought or flooding, respectively), the $A$ and $g_{s}$ decreased significantly $\left(2.0 \mu \mathrm{mol} \mathrm{m}^{-2} \mathrm{~s}^{-1}\right.$ and $12 \mathrm{mmol} \mathrm{m}^{-2} \mathrm{~s}^{-1}$, respectively) compared with the control plants.

In the second treatment (starting with day 16), the plants that were already in drought were placed in flooding, and both parameters $\left(A\right.$ and $\left.g_{s}\right)$ started to recover until day 24 (at $17.2 \mu \mathrm{mol} \mathrm{m} \mathrm{m}^{-2} \mathrm{~s}^{-1}$ for $A$ and $70 \mathrm{mmol} \mathrm{m}{ }^{-2} \mathrm{~s}^{-1}$ for $g_{s}$ ), followed by a slight decrease until day 29. The plants which had been watered normally ("recovery treatment"), the assimilation rates, and stomatal conductance to water vapor recovered at the level of control plants. In the case of the plants in which the first treatment was flooding and the second one drought, both parameters increased for the first three days and decreased drastically until day 29 (at $0.3 \mu \mathrm{mol} \mathrm{m}{ }^{-2} \mathrm{~s}^{-1}$ for $A$ and $29 \mathrm{mmol} \mathrm{m}^{-2} \mathrm{~s}^{-1}$ for $g_{s}$ ). Plants 
that were in the recovery treatment showed $A$ and $g_{s}$ at a level of $16.6 \mu \mathrm{mol} \mathrm{m}{ }^{-2} \mathrm{~s}^{-1}$ and $84 \mathrm{mmol} \mathrm{m}^{-2} \mathrm{~s}^{-1}$, respectively.

\subsection{The Influence of Stress on Volatile Organic Compounds Emission}

Different green leaf volatile compounds (GLV) and monoterpenes (MT) have been identified in the blend of volatile emission from O. basilicum leaves (Figure 3). The GLV identified in plants subjected to abiotic stresses were 3-methyl-pentane and 1-hexanol, and the MT identified were: alpha-pinene, camphene, sabinene, beta-pinene, 3-carene, D-limonene, gamma-terpinene, linalool, camphor, and alpha-terpineol.

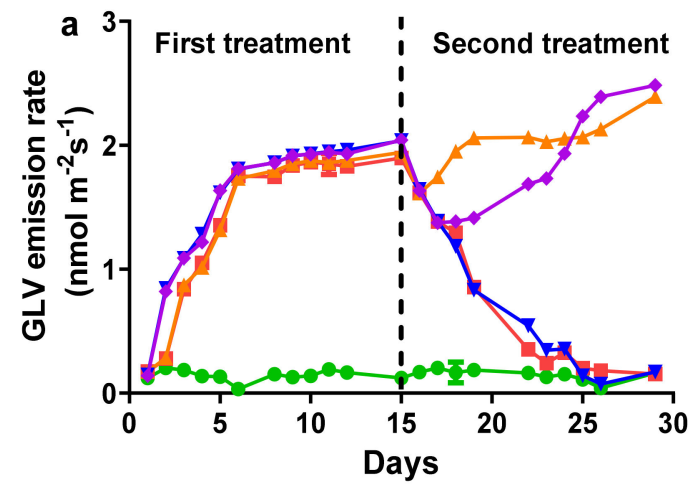

(a)

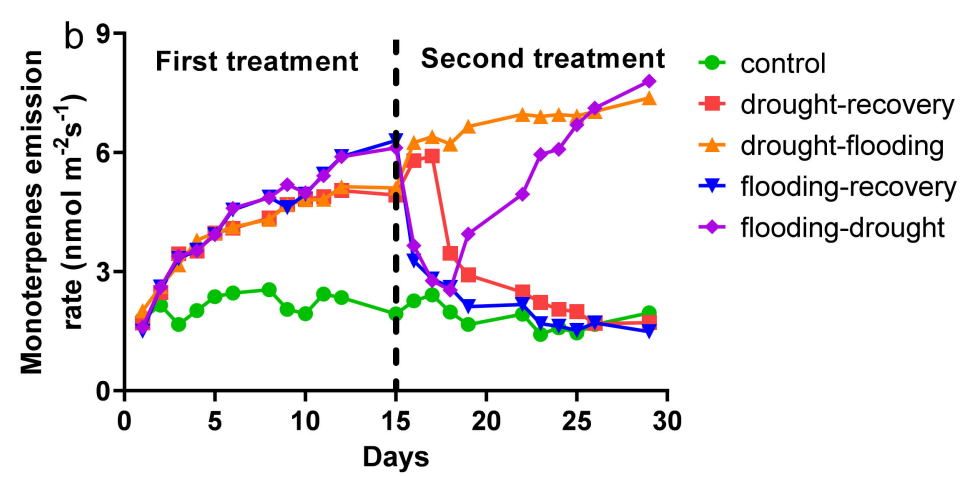

(b)

Figure 3. The emission rate of green leaf volatile compounds (GLV) (a) and monoterpenes (b) from O. basilicum plants under different stress conditions.

The green leaf volatile emission for control plants is close to zero over all of the experiments. In the plants under flooding and drought stresses, the emission increases at a maximum of $2.43 \pm 0.14 \mathrm{nmol} \mathrm{m}^{-2} \mathrm{~s}^{-1}$ on day 15 without statistically significant differences between first flooding or drought (Figure 3a). The emission for plants that were watered normally in the second treatment decreases close to zero on day 29. In contrast, the plants which were subject to the second treatment (flooding or drought stress) first decrease the emission (for one day in case of drought-flooding and three days for flooding-drought) followed by an increase until $2.48 \pm 0.44 \mathrm{nmol} \mathrm{m}^{-2} \mathrm{~s}^{-1}$.

The leaves from $O$. basilicum emit different monoterpenes (MT) constitutively. The total average emission of MT from control leaves is $2.00 \pm 0.34 \mathrm{nmol} \mathrm{m}^{-2} \mathrm{~s}^{-1}$. For plants under drought and flooding stress (as first treatment), the MT emissions increase until $5.10 \pm 0.60 \mathrm{nmol} \mathrm{m}^{-2} \mathrm{~s}^{-1}$ and $6.29 \pm 0.57 \mathrm{nmol} \mathrm{m}^{-2} \mathrm{~s}^{-1}$ respectively. For plants that were watered normally in the second treatment, the emission decreases until the level of control plants. In contrast, the emission from leaves from drought-flooding and flooding-drought plants decreases initially, followed by a sharp increase until $7.37 \pm 0.07 \mathrm{nmol} \mathrm{m}^{-2} \mathrm{~s}^{-1}$ (Figure 3b).

\subsection{The Effects of Antagonistic Stress on Photosynthetic Pigments}

The pigment content in basil leaves was affected by flooding and drought stress (Figure 4). The concentrations of chlorophylls $a$ and $b$ decreased significantly for all stress treatments compared with the values found in the leaves of control plants.

Moreover, there are lower concentrations for both chlorophylls in plants that had been under a second stress (drought-flooding and flooding-drought) compared with the plants under one stress (drought-recovery and flooding-recovery).

The $\beta$-carotene contents in leaves of plants under drought stress were more than half compared with the control leaves $(0.20 \pm 0.02 \mu \mathrm{g} / \mathrm{mg}$ FW compared with $0.46 \pm 0.02 \mu \mathrm{g} / \mathrm{mg}$ FW) The pigment concentration in leaves under drought-flooding has been found significantly 
lower than for drought-recovery. For the flooding-drought treatment, the values did not significantly decrease compared with flooding-recovery.

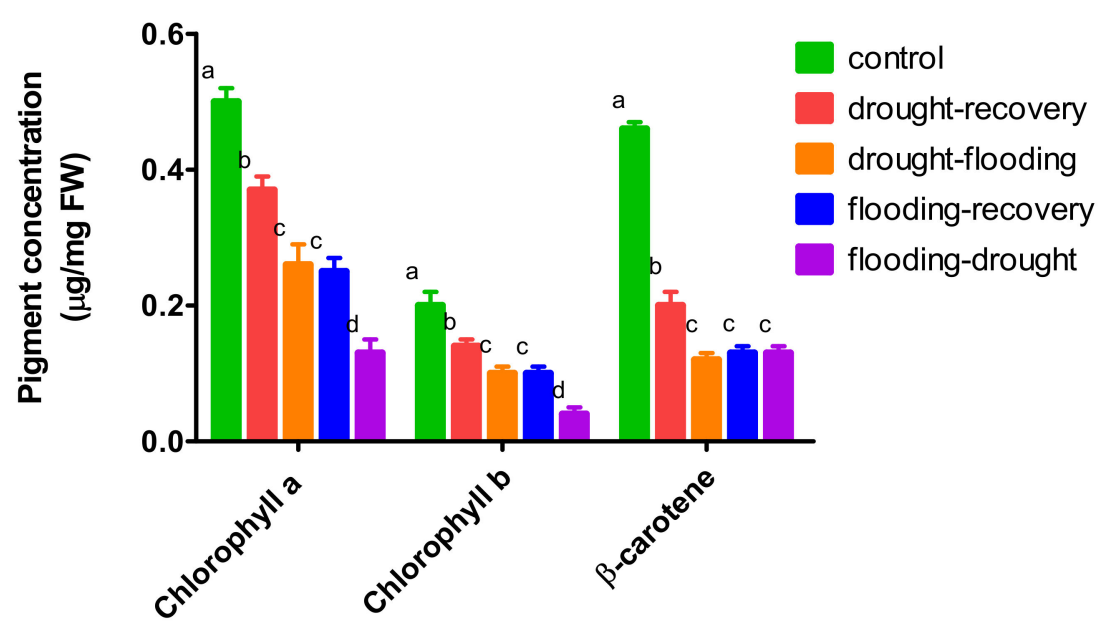

Figure 4. Pigment concentration from O. basilicum leaves under different stress conditions.

\subsection{The Effects of Antagonistic Stress on Total Flavonoid Content}

As has been observed in Figure 5, the total flavonoid content in basil leaves decreases for all stresses compared with control from $90 \pm 10 \mathrm{mg}$ rutin equivalents $/ \mathrm{mL}$ to $39 \pm 6 \mathrm{mg}$ rutin equivalents $/ \mathrm{mL}(p<0.001)$. There are no statistical differences between different stress treatments $(p=0.103)$.

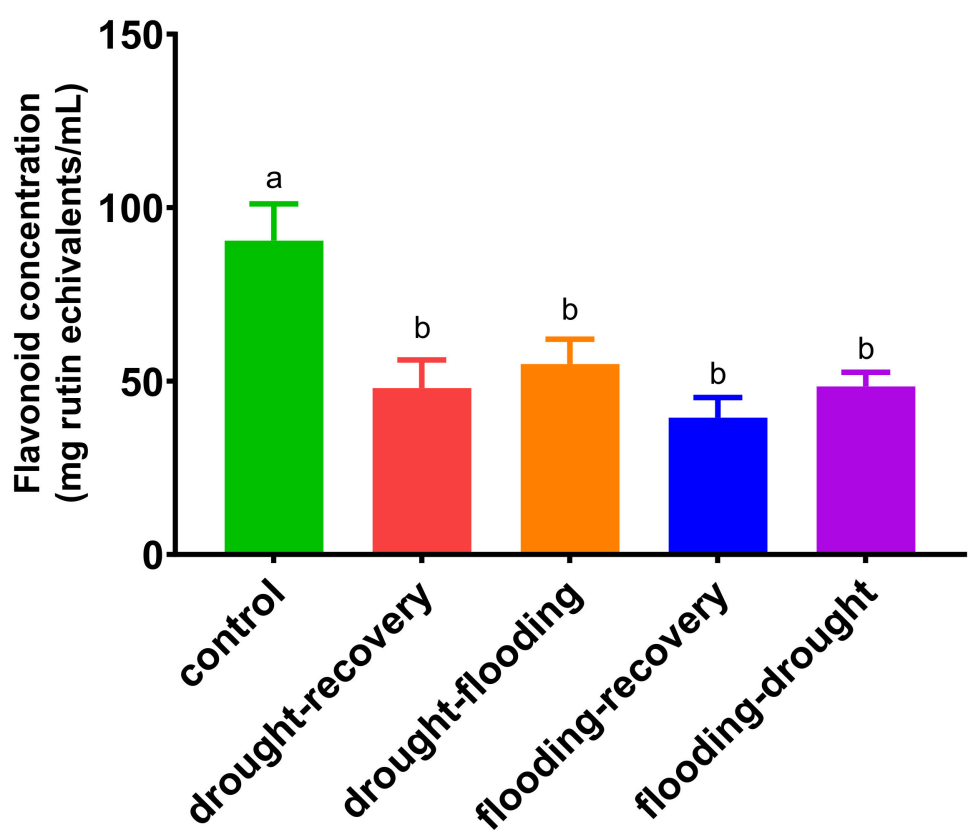

Figure 5. Total flavonoid concentration in O. basilicum leaves under different stress conditions.

\subsection{The Effects of Antagonistic Stress on Total Phenolic Content-Folin-Ciocalteu Method}

As has been depicted in Figure 6, the total phenolic compounds in control leaves decrease for plants subject to stress conditions from $596 \pm 35 \mathrm{mg}$ gallic acid equivalents $/ \mathrm{mL}$ to $296 \pm 30 \mathrm{mg}$ gallic acid equivalents $/ \mathrm{mL}$ in the flooding-recovery treatment. The concentration of phenolic compounds did not change for the plants under the second treatment for both flooding and drought. Conversely, the concentrations are statistically different from drought compared with flooding $(p<0.001)$. 


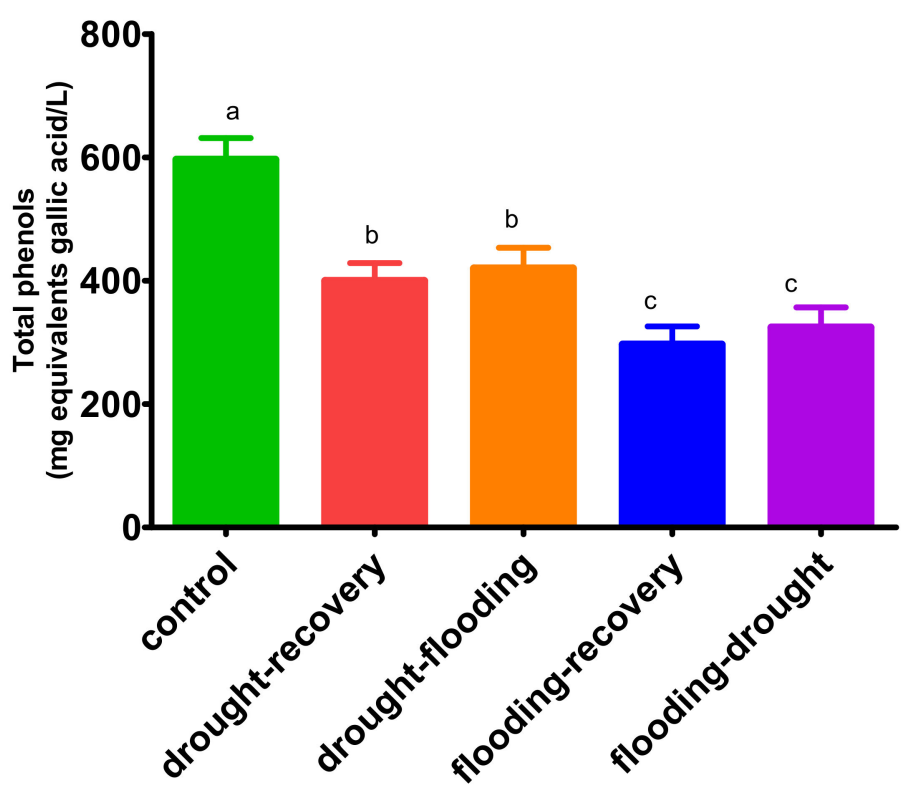

Figure 6. Total concentration of phenols in O. basilicum leaves under different stress conditions.

\section{Discussion}

Flooding and drought stress modifies a plethora of plant physiological functions ranging from cellular to organ. Plant roots are the first organs that sense the water limitation or excess, signaling stomatal closure and decreasing the carbon dioxide assimilation. In our experiment, the stomata conductance $\left(g_{s}\right)$ for plants under flooding and drought falls over the days of stress. In drought stress, stomatal conductance to water vapor decreases faster than for flooding. In contrast, the assimilation rate is more affected by flooding than drought. It has been shown that under drought conditions, the plant growth process is slowed down [42], and due to stomata closure, there are limitations of the diffusion of $\mathrm{CO}_{2}$ to chloroplasts [43]. Long-time exposure to drought often modifies phytohormonal levels in plants, including abscisic acids, salicylic acid, jasmonate, and other metabolites [44]. Such behavior has been found for different $C_{3}$ plants in which drought mainly binds photosynthesis through stomatal closure [45]. The assimilation rate is decreasing as stomatal limitations dominate, irrespective of any metabolic impairment for mild drought stress. Furthermore, after re-hydration, the $g_{s}$ did not recover at the same values, suggesting permanent damage of the photosynthetic apparatus. Usually, high humidity determines the stomata opening, but all photosynthetic parameters decrease under the long flooding period. For example, soil flooding Lycopersicon esculentum plants induce stomata closure within a few hours [46] while Pisum sativum L. stomata close after $24 \mathrm{~h}$ from the start of flooding [46]. This stomatal closure under flooding may be due to the discharge of stress ethylene [47]. Basil plants exposed to flooding have reduced oxygen availability (hypoxia) in plant roots, being that it is difficult for gas diffusion to occur in the plant cells, which thus limits the gas exchange for photosynthesis and transpiration [48]. For plants under antagonist stresses, both photosynthesis parameters are decreasing despite which stress is the first one. For the flooding-drought plants, stomatal conductance to water vapor and assimilation rate decrease drastically at the end of the second treatment (day 29). Such behavior could be explained by the fact that flooding decreases contents of ribulose biphosphate and adenosine triphosphate, and in drought, the processes continue [45]. Moreover, for the plants under drought-flooding stress, such metabolic processes are less important.

Plant species are triggering emissions of various characteristic stress volatiles in response to different abiotic stress (drought and flooding). The first compounds emitted from leaves under stress conditions are green leaf volatiles (GLVs). Those compounds include various five- and six-carbon alcohols, aldehydes, and ketones and are formed through the oxylipin pathway from $\mathrm{C}_{18}$-polyunsaturated fatty acids as $\alpha$-linolenic acid or linoleic 
acid [49,50]. The emission of GLVs from basil leaves under drought and flooding stress starts from the first day and increases until a maximum, followed by a plateau. The same effect has been shown for the lipoxygenase activity during drought stress in Rosmarinus of ficinalis [51] and the leaves of Q. robur trees exposed to drought stress [52]. Such an increase in GLV emissions could be due to the damage of the physical membrane as the enrichment of the lipoxygenase activity [53]. For the combined treatments, drought-flooding and flooding-drought, the emission of GLVs initially decreases, followed by an increase until a maximum. Such behavior has been shown for combined stress like drought and ozone [52] and corresponds to the effects of the lipoxygenase and hydroperoxide lyase systems which release those aldehydes and alcohols.

Because sweet basil is a very well-known spice worldwide due to its distinctively sweet odor and flavor, many investigations have been conducted to investigate the composition of terpenes in O. basilicum emission [14-16,28,29,54-56]. The volatile emission from basil leaves is mainly alpha-pinene, camphene, sabinene, beta-pinene, 3-carene, D-limonene, gamma-terpinene, linalool, camphor, and alpha-terpineol. The total emission of monoterpenes increases for plants under drought and flooding stress. The same pattern has been found for constitutively monoterpene-emitting species under drought [57-60] and flooding stress [61]. For plants under a second stress, the emission increase at the second maxim suggests overexpression of the non-mevalonate (MEP) pathway genes as terpene synthase [62]. Under drought or flooding stress, the volatile isoprenoid compounds can protect against abiotic stress when the stomata close. Furthermore, volatiles can protect against abiotic stress by stabilizing membranes and serving as antioxidants [63]. Some other compounds that can act as an elicitor to improve secondary metabolism S. officinalis plants were found to be nano- $\mathrm{TiO}_{2}$ [64].

Drought stress is one of the most severe limitations to photosynthesis, decreasing carotenoid pigments in the leaves. Lower chlorophyll content under drought stress may help plants reduce photooxidative damage, which occurs when photosynthesis is inhibited $[65,66]$. The chlorophyll $a$ and $b$ decrease in the leaves of plants under flooding stress compared with the control. Even more, the reduction is more production for plants under flooding-drought stress. The decline in photosynthetic pigments could be due to slow synthesis, fast destruction of chlorophylls, or a nitrogen deficiency due to dilution and leaching. Drought stress also induces leaf necrosis due to the lack of anthocyanin pigments in the late stage of vegetation [67]. The effects of drought stress can be compensated by applying a small quantity of putrescine $\left(20 \mathrm{mg} \mathrm{L}^{-1}\right)$ in Thymus vulgaris L. plants, which leads to a higher yield of essential oil $(23.07 \%)[68,69]$.

The phenylpropanoid pathway in plants is disturbed by different abiotic factors such as cold, heat, drought, salinity, heavy metal toxicity, etc. [70]. Drought stress usually enhances phenolic acids and flavonoids [71]. Under drought conditions, the accumulation of glycine betaine was recognized to have positive functions in maintaining the integrity and stability of the membrane of cells [72].

Numerous studies have reported that the quality of products obtained from medicinal plants can be improved by applying drought stress [73-75]. In case of drought, flooding, and salt stress, due to stomata closure, the stress-induced synthesis and buildup of secondary metabolites, such as isoprenoids and phenolic compounds, is observed. This is an effect of oversupply of $\mathrm{NADPH}^{+} \mathrm{H}^{+}$from the Calvin cycle due to a decrease in $\mathrm{CO}_{2}$ fixation $[73,74]$, compared to plants grown in the normal condition which assimilates carbon and energy from photosynthesis and utilizes a part of it for cell maintenance, while the other part is used for plant growth and the synthesis of defensive compounds [73].

In contrast, in our study, the total flavonoids and phenols decrease for plants under stress conditions. It has been shown that severe drought induced a decrease of total flavonoids and phenols in leaves of Quercus ilex [76]. Such decreasing could indicate a lower capacity to regulate reactive oxygen species and the oxidative load in O. basilicum, a relative stress-sensitive species [77]. 


\section{Conclusions}

Considering the results obtained, drought and flooding cause physiological and metabolic alterations in the leaves of $O$. basilicum plants. The net assimilation rates and stomatal conductance to water vapor decrease drastically for plants under consecutive stresses, and emission of volatile organic compounds is enhanced (from 0.14 to $2.48 \mathrm{nmol} \mathrm{m}^{-2} \mathrm{~s}^{-1}$ ). Moreover, the emission of monoterpenes increased, especially for plants under drought-flooding stresses. A decrease in all the photosynthetic pigments was noticed. In chlorophyll $a$ and $b$, a decrease was observed from 0.50 to $0.13,0.20$ to $0.04 \mu \mathrm{g} / \mathrm{mg} \mathrm{FW}$, and for $\beta$-carotene from 0.46 to $0.20 \mu \mathrm{g} / \mathrm{mg} \mathrm{FW}$. The flavonoid content also decreased in all plants subjected to abiotic stress. The treatment that had a significant impact on the basil plants was flooding, followed by drought. The minor influence had drought followed by recovery stage, and flooding followed by recovery stage. Our findings suggest that parameters are affected by basil plants' water status (drought and/or flooding), but even after 15 days of treatment, they can recover almost at the initial parameters. If antagonist stress is applied after this period, all plant parameters drastically decrease.

Author Contributions: Conceptualization, L.C., A.L., C.M., and D.M.C.; methodology, L.C., A.L., M.T., and C.M.; software, L.C., A.L., and D.M.C.; validation, L.C., A.L., C.M., and D.M.C.; formal analysis, A.L., L.C., C.M., and D.M.C.; investigation, L.C., A.L., C.M., M.T., and D.M.C.; resources, L.C., A.L., C.M., and D.M.C.; data curation, L.C., and A.L.; writing-original draft preparation, L.C., A.L., and M.T.; writing-review and editing, L.C. and A.L.; visualization, L.C., A.L., C.M., M.T., and D.M.C.; supervision, L.C.; project administration, A.L. and L.C.; funding acquisition, A.L. and L.C. All authors have read and agreed to the published version of the manuscript.

Funding: This work was supported by a grant of the Romanian Ministry of Education and Research, CNCS-UEFISCDI, project number PN-III-P1-1.1-PD-2019-0349, within PNCDI III.

Institutional Review Board Statement: Not applicable.

Informed Consent Statement: Not applicable.

Data Availability Statement: No available.

Conflicts of Interest: The authors declare no conflict of interest.

\section{References}

1. Singh, D.; Chaudhuri, P.K. A review on phytochemical and pharmacological properties of Holy basil (Ocimum sanctum L.). Ind. Crops Prod. 2018, 118, 367-382. [CrossRef]

2. Dafni, A.; Petanidou, T.; Vallianatou, I.; Kozhuharova, E.; Blanché, C.; Pacini, E.; Peyman, M.; Stevanovic, Z.D.; Franchi, G.G.; Benítez, G. Myrtle, Basil, Rosemary, and Three-Lobed Sage as Ritual Plants in the Monotheistic Religions: An HistoricalEthnobotanical Comparison. Econ. Bot. 2020, 74, 330-355. [CrossRef]

3. Shahrajabian, M.H.; Sun, W.; Cheng, Q. Chemical components and pharmacological benefits of Basil (Ocimum basilicum): A review. Int. J. Food Prop. 2020, 23, 1961-1970. [CrossRef]

4. Ademiluyi, A.O.; Oyeleye, S.I.; Oboh, G. Biological activities, antioxidant properties and phytoconstituents of essential oil from sweet basil (Ocimum basilicum L.) leaves. Comp. Clin. Path. 2016, 25, 169-176. [CrossRef]

5. Majdi, C.; Pereira, C.; Dias, M.I.; Calhelha, R.C.; Alves, M.J.; Rhourri-Frih, B.; Charrouf, Z.; Barros, L.; Amaral, J.S.; Ferreira, I.C.F.R. Phytochemical Characterization and Bioactive Properties of Cinnamon Basil (Ocimum basilicum cv. 'Cinnamon') and Lemon Basil (Ocimum $\times$ citriodorum). Antioxidants 2020, 9, 369. [CrossRef]

6. Jiang, Y.; Ye, J.; Li, S.; Niinemets, Ü. Regulation of floral terpenoid emission and biosynthesis in sweet basil (Ocimum basilicum). J. Plant Growth Regul. 2016, 35, 921-935. [CrossRef]

7. Avetisyan, A.; Markosian, A.; Petrosyan, M.; Sahakyan, N.; Babayan, A.; Aloyan, S.; Trchounian, A. Chemical composition and some biological activities of the essential oils from basil Ocimum different cultivars. BMC Complement. Altern. Med. 2017, 17, 60. [CrossRef]

8. Da Costa, A.S.; Arrigoni-Blank, M.d.F.; Carvalho Filho, J.L.S.d.; de Santana, A.D.D.; Santos, D.d.A.; Alves, P.B.; Blank, A.F. Chemical Diversity in Basil (Ocimum sp.) Germplasm. Sci. World J. 2015, 2015, 352638. [CrossRef]

9. Zheljazkov, V.D.; Callahan, A.; Cantrell, C.L. Yield and Oil Composition of 38 Basil ( Ocimum basilicum L.) Accessions Grown in Mississippi. J. Agric. Food Chem. 2008, 56, 241-245. [CrossRef]

10. Liber, Z.; Carović-Stanko, K.; Politeo, O.; Strikić, F.; Kolak, I.; Milos, M.; Satovic, Z. Chemical characterization and genetic relationships among Ocimum basilicum L. cultivars. Chem. Biodivers. 2011, 8, 1978-1989. [CrossRef] 
11. Soran, M.-L.; Stan, M.; Niinemets, Ü.; Copolovici, L. Influence of microwave frequency electromagnetic radiation on terpene emission and content in aromatic plants. J. Plant Physiol. 2014, 171, 1436-1443. [CrossRef]

12. Copolovici, L.; Pag, A.; Kännaste, A.; Bodescu, A.; Tomescu, D.; Copolovici, D.; Soran, M.-L.; Niinemets, Ü. Disproportionate photosynthetic decline and inverse relationship between constitutive and induced volatile emissions upon feeding of Quercus robur leaves by large larvae of gypsy moth (Lymantria dispar). Environ. Exp. Bot. 2017, 138, 184-192. [CrossRef]

13. Barbieri, G.; Vallone, S.; Orsini, F.; Paradiso, R.; De Pascale, S.; Negre-Zakharov, F.; Maggio, A. Stomatal density and metabolic determinants mediate salt stress adaptation and water use efficiency in basil (Ocimum basilicum L.). J. Plant Physiol. 2012, 169, 1737-1746. [CrossRef]

14. Prinsi, B.; Morgutti, S.; Negrini, N.; Faoro, F.; Espen, L. Insight into Composition of Bioactive Phenolic Compounds in Leaves and Flowers of Green and Purple Basil. Plants 2020, 9, 22. [CrossRef]

15. Złotek, U.; Mikulska, S.; Nagajek, M.; Świeca, M. The effect of different solvents and number of extraction steps on the polyphenol content and antioxidant capacity of basil leaves (Ocimum basilicum L.) extracts. Saudi J. Biol. Sci. 2016, 23, 628-633. [CrossRef]

16. Ghasemzadeh, A.; Ashkani, S.; Baghdadi, A.; Pazoki, A.; Jaafar, H.Z.; Rahmat, A. Improvement in flavonoids and phenolic acids production and pharmaceutical quality of sweet basil (Ocimum basilicum L.) by ultraviolet-B irradiation. Molecules 2016, $21,1203$. [CrossRef] [PubMed]

17. Schiermeier, Q. Droughts, heatwaves and floods: How to tell when climate change is to blame. Nature 2018, 560, 20-23. [CrossRef]

18. Kalantari, Z.; Ferreira, C.S.S.; Keesstra, S.; Destouni, G. Nature-based solutions for flood-drought risk mitigation in vulnerable urbanizing parts of East-Africa. Curr. Opin. Environ. Sci. 2018, 5, 73-78. [CrossRef]

19. Šamec, D.; Karalija, E.; Šola, I.; Vujčić Bok, V.; Salopek-Sondi, B. The Role of Polyphenols in Abiotic Stress Response: The Influence of Molecular Structure. Plants 2021, 10, 118. [CrossRef]

20. Xu, Z.; Zhou, G.; Shimizu, H. Plant responses to drought and rewatering. Plant Signal. Behav. 2010, 5, 649-654. [CrossRef] [PubMed]

21. Geber, M.A.; Dawson, T.E. Genetic variation in and covariation between leaf gas exchange, morphology, and development in Polygonum arenastrum, an annual plant. Oecologia 1990, 85, 153-158. [CrossRef]

22. Lee, Y.; Rubio, M.C.; Alassimone, J.; Geldner, N. A mechanism for localized lignin deposition in the endodermis. Cell 2013, 153, 402-412. [CrossRef]

23. Balducci, L.; Deslauriers, A.; Giovannelli, A.; Beaulieu, M.; Delzon, S.; Rossi, S.; Rathgeber, C.B.K. How do drought and warming influence survival and wood traits of Picea mariana saplings? J. Exp. Bot. 2014, 66, 377-389. [CrossRef] [PubMed]

24. Beikircher, B.; De Cesare, C.; Mayr, S. Hydraulics of high-yield orchard trees: A case study of three Malus domestica cultivars. Tree Physiol. 2013, 33, 1296-1307. [CrossRef]

25. Duan, B.; Lu, Y.; Yin, C.; Junttila, O.; Li, C. Physiological responses to drought and shade in two contrasting Picea asperata populations. Physiol. Plant. 2005, 124, 476-484. [CrossRef]

26. Jeandroz, S.; Lamotte, O. Editorial: Plant Responses to Biotic and Abiotic Stresses: Lessons from Cell Signaling. Front. Plant Sci. 2017, 8, 1772. [CrossRef]

27. Niinemets, Ü. Uncovering the hidden facets of drought stress: Secondary metabolites make the difference. Tree Physiol. 2015, 36, 129-132. [CrossRef] [PubMed]

28. Jayasinghe, C.; Gotoh, N.; Aoki, T.; Wada, S. Phenolics composition and antioxidant activity of sweet basil (Ocimum basilicum L.). J. Agric. Food Chem. 2003, 51, 4442-4449. [CrossRef]

29. Al-Huqail, A.; El-Dakak, R.M.; Sanad, M.N.; Badr, R.H.; Ibrahim, M.M.; Soliman, D.; Khan, F. Effects of Climate Temperature and Water Stress on Plant Growth and Accumulation of Antioxidant Compounds in Sweet Basil (Ocimum basilicum L.) Leafy Vegetable. Scientifica 2020, 2020, 3808909. [CrossRef]

30. Kalisz, A.; Jezdinský, A.; Pokluda, R.; Sękara, A.; Grabowska, A.; Gil, J. Impacts of chilling on photosynthesis and chlorophyll pigment content in juvenile basil cultivars. Hortic. Environ. Biotechnol. 2016, 57, 330-339. [CrossRef]

31. Kordi, S.; Saidi, M.; Ghanbari, F. Induction of drought tolerance in sweet basil (Ocimum basilicum L.) by salicylic acid. Int. J. Agric. Food Res. 2013, 2, 18-26. [CrossRef]

32. Lazarević, B.; Šatović, Z.; Nimac, A.; Vidak, M.; Gunjača, J.; Politeo, O.; Carović-Stanko, K. Application of Phenotyping Methods in Detection of Drought and Salinity Stress in Basil (Ocimum basilicum L.). Front. Plant Sci. 2021, 12, 174. [CrossRef] [PubMed]

33. Barickman, T.C.; Olorunwa, O.J.; Sehgal, A.; Walne, C.H.; Reddy, K.R.; Gao, W. Yield, Physiological Performance, and Phytochemistry of Basil (Ocimum basilicum L.) under Temperature Stress and Elevated $\mathrm{CO}_{2}$ Concentrations. Plants 2021, $10,1072$. [CrossRef]

34. Copolovici, L.; Kännaste, A.; Pazouki, L.; Niinemets, Ü. Emissions of green leaf volatiles and terpenoids from Solanum lycopersicum are quantitatively related to the severity of cold and heat shock treatments. J. Plant Physiol. 2012, 169, 664-672. [CrossRef]

35. Niinemets, Ü.; Copolovici, L.; Hüve, K. High within-canopy variation in isoprene emission potentials in temperate trees: Implications for predicting canopy-scale isoprene fluxes. J. Geophys. Res. Biogeosci. 2010, 115, G04029. [CrossRef]

36. Kännaste, A.; Copolovici, L.; Niinemets, Ü. Gas chromatography-mass spectrometry method for determination of biogenic volatile organic compounds emitted by plants. In Plant Isoprenoids; Humana Press: New York, NY, USA, 2014; pp. 161-169.

37. Toome, M.; Randjärv, P.; Copolovici, L.; Niinemets, Ü.; Heinsoo, K.; Luik, A.; Noe, S.M. Leaf rust induced volatile organic compounds signalling in willow during the infection. Planta 2010, 232, 235-243. [CrossRef] 
38. Niinemets, Ü.; Kuhn, U.; Harley, P.C.; Staudt, M.; Arneth, A.; Cescatti, A.; Ciccioli, P.; Copolovici, L.; Geron, C.; Guenther, A. Estimations of isoprenoid emission capacity from enclosure studies: Measurements, data processing, quality and standardized measurement protocols. Biogeosciences 2011, 8, 2209-2246. [CrossRef]

39. Opriş, O.; Copaciu, F.; Soran, M.L.; Ristoiu, D.; Niinemets, Ü.; Copolovici, L. Influence of nine antibiotics on key secondary metabolites and physiological characteristics in Triticum aestivum: Leaf volatiles as a promising new tool to assess toxicity. Ecotoxicol. Environ. 2013, 87, 70-79. [CrossRef]

40. Pag, A.I.; Radu, D.G.; Popa, M.I.; Sirghie, C. Flaxseed cake-a sustainable source of antioxidant and antibacterial extracts. Cell. Chem. Technol. 2014, 48, 265-273.

41. Moisa, C.; Copolovici, L.; Pop, G.; Imbrea, I.; Lupitu, A.; Nemeth, S.; Copolovici, D. Wastes resulting from aromatic plants distillation-bio-sources of antioxidants and phenolic compounds with biological active principles. Farmacia 2018, 66, $289-295$.

42. Damalas, C.A. Improving drought tolerance in sweet basil (Ocimum basilicum) with salicylic acid. Sci. Hortic. 2019, 246, 360-365. [CrossRef]

43. Cornic, G. Drought stress inhibits photosynthesis by decreasing stomatal aperture - not by affecting ATP synthesis. Trends Plant Sci. 2000, 5, 187-188. [CrossRef]

44. Agurla, S.; Gahir, S.; Munemasa, S.; Murata, Y.; Raghavendra, A.S. Mechanism of Stomatal Closure in Plants Exposed to Drought and Cold Stress. Adv. Exp. Med. Biol. 2018, 1081, 215-232. [CrossRef]

45. Flexas, J.; Medrano, H. Drought-inhibition of Photosynthesis in $\mathrm{C}_{3}$ Plants: Stomatal and Non-stomatal Limitations Revisited. Ann. Bot. 2002, 89, 183-189. [CrossRef] [PubMed]

46. Jackson, M.B.; Hall, K.C. Early stomatal closure in waterlogged pea plants is mediated by abscisic acid in the absence of foliar water deficits. Plant Cell Environ. 1987, 10, 121-130. [CrossRef]

47. Blanke, M.M.; Cooke, D.T. Effects of flooding and drought on stomatal activity, transpiration, photosynthesis, water potential and water channel activity in strawberry stolons and leaves. Plant Growth Regul. 2004, 42, 153-160. [CrossRef]

48. Salazar, C.; Hernández, C.; Pino, M.T. Plant water stress: Associations between ethylene and abscisic acid response. Chil. J. Agric. Res. 2015, 75, 71-79. [CrossRef]

49. Ameye, M.; Allmann, S.; Verwaeren, J.; Smagghe, G.; Haesaert, G.; Schuurink, R.C.; Audenaert, K. Green leaf volatile production by plants: A meta-analysis. New Phytol. 2018, 220, 666-683. [CrossRef] [PubMed]

50. Matsui, K.; Sugimoto, K.; Mano, J.; Ozawa, R.; Takabayashi, J. Differential metabolisms of green leaf volatiles in injured and intact parts of a wounded leaf meet distinct ecophysiological requirements. PloS ONE 2012, 7, e36433. [CrossRef] [PubMed]

51. Liu, F.; Xu, G.-P.; Zheng, J.; Gao, R.-F.; Zhang, R.-M.; Wu, X.-B.; Gao, Y.; Zuo, Z.-J. Physiological responses to drought stress and the emission of induced volatile organic compounds in Rosmarinus officinalis. Chin. J. Plant Ecol. 2013, 37, 454-463. [CrossRef]

52. Peron, A.; Kaser, L.; Fitzky, A.C.; Graus, M.; Halbwirth, H.; Greiner, J.; Wohlfahrt, G.; Rewald, B.; Sandén, H.; Karl, T. Combined effects of ozone and drought stress on the emission of biogenic volatile organic compounds from Quercus robur L. Biogeosciences 2021, 18, 535-556. [CrossRef]

53. Wenda-Piesik, A. Volatile Organic Compound Emissions by Winter Wheat Plants (Triticum aestivum L.) under Fusarium spp. Infestation and Various Abiotic Conditions. Pol. J. Environ. Stud. 2011, 20, 1335-1342.

54. Carlo, N.; Silvia, S.; Stefano, B.; Paolo, S. Influence of cut number on qualitative traits in different cultivars of sweet basil. Ind. Crops Prod. 2013, 44, 465-472. [CrossRef]

55. Shiga, T.; Shoji, K.; Shimada, H.; Hashida, S.-n.; Goto, F.; Yoshihara, T. Effect of light quality on rosmarinic acid content and antioxidant activity of sweet basil, Ocimum basilicum L. Plant Biotechnol. 2009, 26, 255-259. [CrossRef]

56. Comite, E.; El-Nakhel, C.; Rouphael, Y.; Ventorino, V.; Pepe, O.; Borzacchiello, A.; Vinale, F.; Rigano, D.; Staropoli, A.; Lorito, M. Bioformulations with Beneficial Microbial Consortia, a Bioactive Compound and Plant Biopolymers Modulate Sweet Basil Productivity, Photosynthetic Activity and Metabolites. Pathogens 2021, 10, 870. [CrossRef]

57. Blanch, J.-S.; Peñuelas, J.; Sardans, J.; Llusià, J. Drought, warming and soil fertilization effects on leaf volatile terpene concentrations in Pinus halepensis and Quercus ilex. Acta Physiol. Plant. 2008, 31, 207. [CrossRef]

58. Ormeño, E.; Mévy, J.P.; Vila, B.; Bousquet-Mélou, A.; Greff, S.; Bonin, G.; Fernandez, C. Water deficit stress induces different monoterpene and sesquiterpene emission changes in Mediterranean species. Relationship between terpene emissions and plant water potential. Chemosphere 2007, 67, 276-284. [CrossRef]

59. Radwan, A.; Kleinwächter, M.; Selmar, D. Impact of drought stress on specialised metabolism: Biosynthesis and the expression of monoterpene synthases in sage (Salvia officinalis). Phytochemistry 2017, 141, 20-26. [CrossRef] [PubMed]

60. Copolovici, L.; Kännaste, A.; Remmel, T.; Niinemets, Ü. Volatile organic compound emissions from Alnus glutinosa under interacting drought and herbivory stresses. Environ. Exp. Bot. 2014, 100, 55-63. [CrossRef]

61. Loreto, F.; Schnitzler, J.-P. Abiotic stresses and induced BVOCs. Trends Plant Sci. 2010, 15, 154-166. [CrossRef] [PubMed]

62. Zeng, X.; Liu, C.; Zheng, R.; Cai, X.; Luo, J.; Zou, J.; Wang, C. Emission and Accumulation of Monoterpene and the Key Terpene Synthase (TPS) Associated with Monoterpene Biosynthesis in Osmanthus fragrans Lour. Front. Plant Sci. 2016, 6, 1232. [CrossRef]

63. Niinemets, Ü.; Kännaste, A.; Copolovici, L. Quantitative patterns between plant volatile emissions induced by biotic stresses and the degree of damage. Front. Plant Sci. 2013, 4, 262. [CrossRef] [PubMed]

64. Ghorbanpour, M. Major essential oil constituents, total phenolics and flavonoids content and antioxidant activity of Salvia officinalis plant in response to nano-titanium dioxide. Indian J. Plant Physiol. 2015, 20, 249-256. [CrossRef] 
65. Aranjuelo, Í.; Molero, G.; Erice, G.; Avice, J.; Nogués, S. Plant physiology and proteomics reveals the leaf response to drought in alfalfa (Medicago sativa L.). J. Exp. Bot. 2011, 62, 111-123. [CrossRef] [PubMed]

66. Chen, D.; Wang, S.; Cao, B.; Cao, D.; Leng, G.; Li, H.; Yin, L.; Shan, L.; Deng, X. Genotypic Variation in Growth and Physiological Response to Drought Stress and Re-Watering Reveals the Critical Role of Recovery in Drought Adaptation in Maize Seedlings. Front. Plant Sci. 2016, 6, 1241. [CrossRef] [PubMed]

67. Arzani, A. Manipulating programmed cell death pathways for enhancing salinity tolerance in crops. In Salinity Responses and Tolerance in Plants, Volume 2; Springer: Cham, Switzerland, 2018; pp. 93-118.

68. Mohammadi, H.; Ghorbanpour, M.; Brestic, M. Exogenous putrescine changes redox regulations and essential oil constituents in field-grown Thymus vulgaris L. under well-watered and drought stress conditions. Ind. Crops Prod. 2018, 122, 119-132. [CrossRef]

69. Raei, M.; Angaji, S.A.; Omidi, M.; Khodayari, M. Effect of abiotic elicitors on tissue culture of Aloe vera. Int. J. Biosci. 2014, 5, 74-81.

70. Sharma, A.; Shahzad, B.; Rehman, A.; Bhardwaj, R.; Landi, M.; Zheng, B. Response of Phenylpropanoid Pathway and the Role of Polyphenols in Plants under Abiotic Stress. Molecules 2019, 24, 2452. [CrossRef]

71. Gharibi, S.; Sayed Tabatabaei, B.E.; Saeidi, G.; Talebi, M.; Matkowski, A. The effect of drought stress on polyphenolic compounds and expression of flavonoid biosynthesis related genes in Achillea pachycephala Rech.f. Phytochemistry 2019, 162, 90-98. [CrossRef]

72. Sytar, O.; Mbarki, S.; Zivcak, M.; Brestic, M. The involvement of different secondary metabolites in salinity tolerance of crops. In Salinity Responses and Tolerance in Plants, Volume 2; Springer: Cham, Switzerland, 2018; pp. 21-48.

73. Yan, K.; Cui, M.; Zhao, S.; Chen, X.; Tang, X. Salinity Stress Is Beneficial to the Accumulation of Chlorogenic Acids in Honeysuckle (Lonicera japonica Thunb.). Front. Plant Sci. 2016, 7, 1563. [CrossRef]

74. Selmar, D.; Kleinwächter, M. Influencing the product quality by deliberately applying drought stress during the cultivation of medicinal plants. Ind. Crops Prod. 2013, 42, 558-566. [CrossRef]

75. Kleinwächter, M.; Selmar, D. New insights explain that drought stress enhances the quality of spice and medicinal plants: Potential applications. Agron. Sustain. Dev. 2015, 35, 121-131. [CrossRef]

76. Pellegrini, E.; Hoshika, Y.; Dusart, N.; Cotrozzi, L.; Gérard, J.; Nali, C.; Vaultier, M.-N.; Jolivet, Y.; Lorenzini, G.; Paoletti, E. Antioxidative responses of three oak species under ozone and water stress conditions. Sci. Total Environ. 2019, 647, 390-399. [CrossRef] [PubMed]

77. Fini, A.; Guidi, L.; Ferrini, F.; Brunetti, C.; Di Ferdinando, M.; Biricolti, S.; Pollastri, S.; Calamai, L.; Tattini, M. Drought stress has contrasting effects on antioxidant enzymes activity and phenylpropanoid biosynthesis in Fraxinus ornus leaves: An excess light stress affair? J. Plant Physiol. 2012, 169, 929-939. [CrossRef] [PubMed] 